13. I. Snook and W. van Megen, J. Chem. Soc., Faraday Trans. II, 72, 216 (1976).

14. K. Takano and S. Hachisu, J. Chem. Phys. 67, 2604 (1977).

15. S. Hachisu and Y. Kobayashi, J. Colloid Int. Sci. 46, 470 (1974).

16. R. Hastings, J. Chem. Phys. 68, 675 (1978).

17. S. L. Brenner, J. Phys. Chem. 80, 1473 (1976).

18. S. Marcelja, D. J. Mitchell, and B. W. Ninham, Chem. Phys, Lett. 43, $353(1976)$

19. A. Kose and S. Hachisu, J. Colloid Int. Sci. 46, 460 (1974).

20. C. J. Barnes, D. Y. C. Chan, D. H. Everett, and D. E. Yates, Chem. Soc. Faraday Trans. II, 74, 136 (1978).

21. S. Hachisu, Y. Kobayashi, and A. Kose, J. Colloid Int. Sci. 42, 342 (1973).

22. V. W. Luck, M. Klier, and H. Wesslau, Naturwissenshaften 50, 485 (1963).

23. T. Alfrey, E. B. Bradford, J. W. Vanderhoff, and G. Oster, J. Opt. Soc. Am. 44, 603 (1954).

24. I. M. Krieger and F. M. O'Neill, J. Am. Chem. Soc. 90, 3114 (1968).

25. P. A. Hiltner and I. M. Krieger, J. Phys. Chem. 73, 2386 (1969).

26. P. A. Hiltner, Y. S. Papir, and I. M. Krieger, J. Phys. Chem. 75, 1881 (1971).

27. K. M. Smith and R. Williams, Endeavor 17, 12 (1958).

28. D. P. Riley and G. Oster, Discuss, Faraday Soc. 11, 107 (1951).

29. R. Williams and R. S. Crandall, Phys. Lett. 48A, 225 (1974).

30. J. W. Goodwin, R. H. Ottewill, and A. Parentich, J. Phys. Chem. 84, $1580(1980)$.

31. N. A. Clark, A. J. Hurd, and B. J. Ackerson, Nature 281, 57 (1979).

32. H. Fujita, K. Ametini, and M. Inoue, RCA Reviews 36, 108 (1975).
33. I. M. Krieger and P. A. Hiltner, Polymer Colloids, R. M. Fitch Ed., Plenum, New York (1975).

34. J. W. Vanderhoff, Pure Appl. Chem. 52, 1263 (1980).

35. J. W. Vanderhoff and H. J. Van Den Hul, J. Macromol. Sci-Chem. A7, 677 (1973); J. Colloid Int. Sci. 28, 336 (1968).

36. L. Barclay, A. Harrington, and R. H. Ottewill, Kooloid-Z,z. Polymere 250, 655 (1972).

37. R. H. Ottewill, Prog. Colloid and Polymer. Sci. 67, 71 (1980).

38. A. Watillon and A.-M. Joseph-Petit, Disc. Faraday Soc. 42, 143 (1966).

39. R. S. Crandall and R. Williams, Science 198, 293 (1977).

40. J. V. Sanders, Nature 204, 1151 (1964).

41. K. Takano and S. Hachisu, J. Colloid Int. Sci. 66, 124 (1978).

42. M. K. Udo and M. F. deSouza, Solid State Comm. 35, 907 (1980).

43. C. Cowell and B. Vincent, J. Colloid Int. Sci. 87, 518 (1982).

44. R. P. Keavey and P. Richmond, J. Chem. Soc. Faraday Trans, II, 72, $773(1976)$.

45. E. Dubois-Violette, P. Pieranski, F. Rothen, and L. Strzelecki, J. de Physique 41, 369 (1980).

46. S. Mitaku, T. Ohtsuku, K. Enari, A. Kishimoto, and K. Okano, Jap. J. Appl. Phys. 17, 305 (1978).

47. P. Pieranski, E. Dubois-Violetti, F. Rothen, and L. Strzelecki, J. de Physique 42, 53 (1981).

48. K. Lonsdale, Phil. Trans. Royal Soc. (London) A, 240, 219 (1947).

49. S. W. Wilkins, Phil. Trans. Royal Soc. (London) A, 299, 275 (1981).

50. B. W. Balterman and H. Cole, Rev. Mod. Phys. 36, 681 (1964).

51. A. Taylor, X-ray Metallography (John Wiley \& Sons, Inc., New York 1961).

\title{
Identification of Inclusions in Lung Tissue with a Raman Microprobe
}

\author{
H. BUITEVELD, F. F. M. DE MUL, J. MUD, and J. GREVE \\ Twente University of Technology, Department of Applied Physics, P.O. Box 217, 7500 AE Enschede, The Netherlands
}

\begin{abstract}
Inhaled particles smaller than $4 \mu \mathrm{m}$ can cause damage to lung tissue, a disease called silicosis. We present an investigation on the use of a Raman microspectrometer for the identification of inclusions in lung tissue. We measured Raman spectra of such inclusions in lung tissue of a patient whose probable cause of death was silicosis. Most of the inclusions we could identify were calcite particles.

Index Headings: Raman; Microprobe; Silicosis; Lung tissue; Inclusions; Pathology.
\end{abstract}

\section{INTRODUCTION}

In recent years several techniques have been developed for the identification of small amounts of material. Some of these techniques make use of microbeams (ion, electron, or proton); others use secondary electrons or $\mathrm{x}$-ray scattering. Usually with these microprobes only the nature of the atoms in the sample is determined. ${ }^{1}$ Recently a Raman microprobe was developed ${ }^{2,3}$ which has the advantage over other microtechniques that chemical identification is feasible without causing damage to the sample or the necessity of staining the sample. Out of an increasing number of applications, we mention

Received 3 February 1983; revision received 8 June 1983. the identification of airborne particles by $\mathrm{Etz}^{4}$ and the analysis of silicone inclusions in lymph tissue by Abraham. ${ }^{5}$

The results presented here were obtained from a study of lung tissue using a Raman microprobe. The lung tissue belonged to a patient who probably died from silicosis or pneumoconiosis. This is caused by small airborne particles embedded in the lung tissue. Some of these particles are removed by macrophages, but others may stay in the lung and cause damage to the tissue. Materials that may cause the disease are silica, silicates, asbestos, or carbonates and related minerals. Identification of the inclusions in the lung tissue is of importance because this might provide a possibility of determining the source of the pollution which caused the disease. In this way one might prevent other exposures.

\section{EXPERIMENTAL}

Thin (5-15 $\mu \mathrm{m})$ paraffinized unstained sections of lung tissue were deposited on normal microscope slides. Before measurement the sections were deparaffinized in xylol, which evaporated afterwards. The sections were analyzed by using polarized light microscopy. This was 


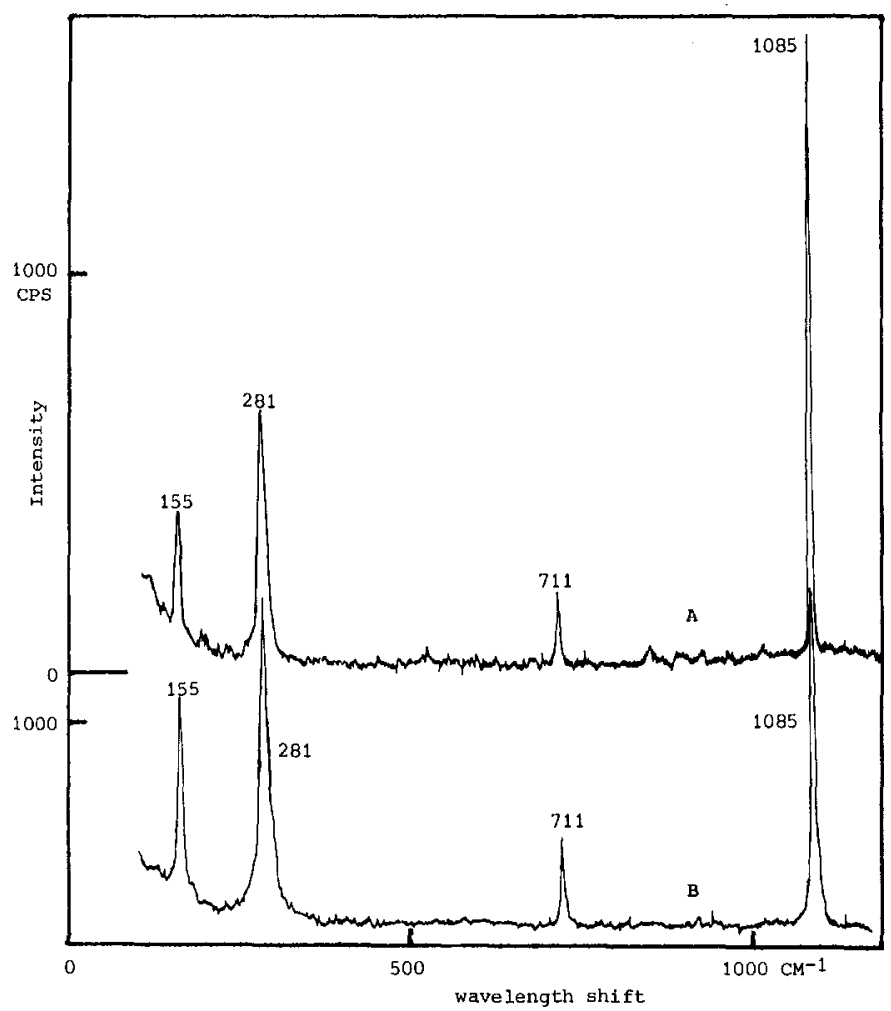

Fig. 1. A, Spectrum of an inclusion in lung tissue $(3 \mu \mathrm{m})$. Laser power at the sample $4 \mathrm{~mW}$; diameter laser spot $1.6 \mu \mathrm{m}$; spectral slit width 3 $\mathrm{cm}^{-1}$; scan rate $50 \mathrm{~cm}^{-1} / \mathrm{min} ; I_{\text {top }}\left(1085 \mathrm{~cm}^{-1}\right)=1500 \mathrm{cps}$. B, Spectrum of a reference calcite particle $(10 \mu \mathrm{m})$, same conditions as in A; $I_{\text {top }}=$ $3500 \mathrm{cps}$.

done to locate the inclusions in the sample. Once a particle was found, its Raman spectrum was recorded.

The measurements were performed using a Raman microspectrometer similar in principle to the one described by Delhaye. ${ }^{2}$ We used a coherent $\mathrm{Ar}^{+}$laser (CR 3) operating at $514.5 \mathrm{~nm}$ as a light source. The laser light passed through the epi-illuminator of a Nikon Optiphot microscope. A $100 \times$ objective $(\mathrm{NA}=0.90)$ was used to focus the beam on the sample (spot diameter 1.6 $\mu \mathrm{m})$. The same objective was used to collect the scattered light and direct it onto an entrance slit of a JobinYvon monochromator (HG 2S). An EMI 9863QB photomultiplier was used for detection. The apparatus was tested with polystyrene spheres of 1- and 10- $\mu \mathrm{m}$ diameter (Dow Chemical). A normal polystyrene spectrum was recorded for both types of particles. With other measurements using polystyrene spheres it was possible to estimate that the effective depth in the particle from which the light was collected lies between 1 and $2 \mu \mathrm{m}$.

The recording of the Raman spectrum of each separate particle in the lung tissue was repeated several times to be sure that no sample deformation took place in the laser spot. No effects of heating or deformation could be detected at the power densities used $\left(\leqq 0.5 \times 10^{9} \mathrm{~W}\right.$. $\mathrm{m}^{-2}$ ). The tissue itself was more sensitive to heating caused by the laser beam. Intensities exceeding $0.5 \times 10^{9}$ $\mathrm{W} \cdot \mathrm{m}^{-2}$ caused visible damage to the tissue. A Raman spectrum of the tissue was not recorded because of the high fluorescent background.

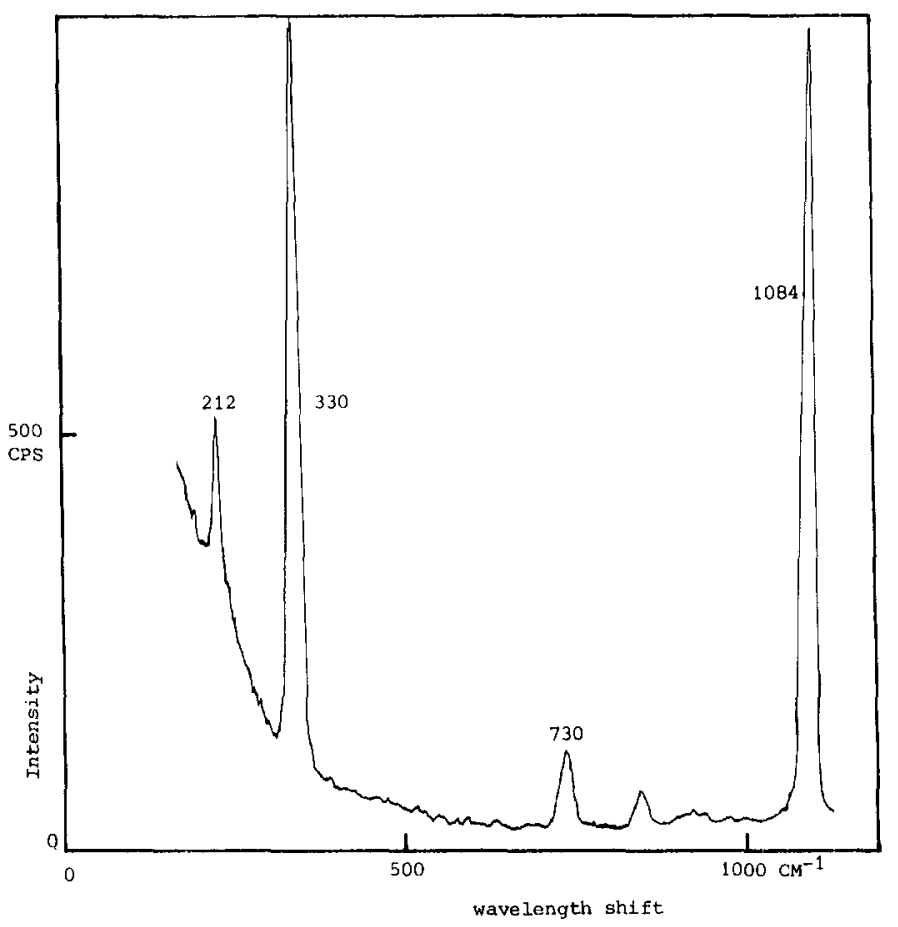

FIG. 2. Spectrum of an inclusion in lung tissue $(4 \mu \mathrm{m})$, probably magnesite; laser power at the sample $5 \mathrm{~mW}$; spectral slit width $5 \mathrm{~cm}^{-1}$; scan rate $20 \mathrm{~cm}^{-1} / \mathrm{min} ; I_{\text {top }}(1084)=900 \mathrm{cps}$.

\section{RESULTS AND DISCUSSION}

Because with stained sections the Raman spectrum has a high background caused by fluorescence of the staining dyes, we used unstained specimens. However, with unstained sections the localization of inclusions by birefringence, using polarized light microscopy, can be very difficult.

In Fig. 1A the Raman spectrum of one of the types of inclusions in the lung tissue sample under investigation is shown. Raman lines are present at frequency shifts of $155,281,711$, and $1085 \mathrm{~cm}^{-1}$. This spectrum is in very good agreement with a reference spectrum of calcite

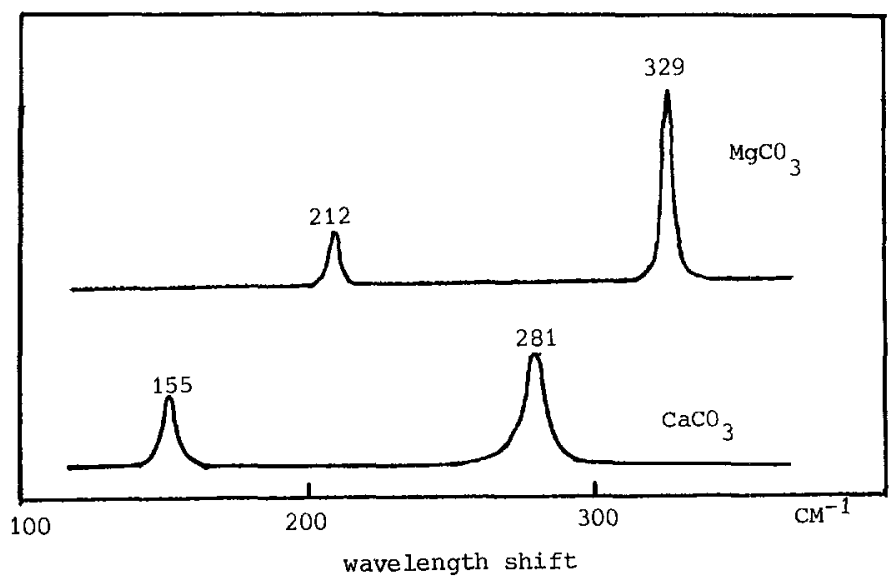

FIG. 3. Low-frequency spectra of reference $\mathrm{MgCO}_{3}$ and $\mathrm{CaCO}_{3}$ taken from literature. ${ }^{7.8}$ Other lines of $\mathrm{MgCO}_{3}$ and $\mathrm{CaCO}_{3}$ are at 739 (w) and $711(\mathrm{~m}), 1084(\mathrm{vs})$, and $1085(\mathrm{vs})$, respectively. ${ }^{7,8}$ 
$\left(\mathrm{CaCO}_{3}\right)$, which was measured with a $10-\mu \mathrm{m}$ particle of pure calcite (Fig. 1B), and with spectra of calcite reported in the literature. ${ }^{6-8}$ The lines at $155,281,711$, and $1085 \mathrm{~cm}^{-1}$ could be assigned to $e_{g}$ (ex), $e_{g}$ (ex), $e_{g}$ (int) and $a_{1 g}$ (int), respectively. ${ }^{7}$ A comparison of the intensity ratios of the lines in the inclusion spectrum with those in the reference spectrum indicates that the crystal structure of the small crystallites present in the tissue is the same as in bulk calcite. Most particles that could be located in the tissue were identified as $\mathrm{CaCO}_{3}$. They varied in size between 2 and $4 \mu \mathrm{m}$.

Another type of inclusion showed Raman lines at 212, 330,730 , and $1084 \mathrm{~cm}^{-1}$ (Fig. 2). This spectrum could be identified as being caused by $\mathrm{MgCO}_{3}$ (magnesite), on the basis of the position (see also Fig. 3) and the relative intensities of the lines, as compared with those of other carbonates. ${ }^{6-8}$ The Raman lines observed in $\mathrm{MgCO}_{3}$ at $212,330,730$, and $1084 \mathrm{~cm}^{-1}$ can be assigned analogously to those of calcite.

In both spectra (Figs. 1 and 2) a line centered around $840 \mathrm{~cm}^{-1}$ is present. This line does not belong to the spectra of calcite or magnesite, but is due to scattering in the microscope objective.

According to medical diagnosis, the cause of death could be silicosis due to inhaled quartz particles. We were able to identify calcite, magnesite, and other material in the present sections; we did not, however, find any quartz particles in these specimens. Later on this was confirmed by $\mathrm{x}$-ray measurement of the tissue. ${ }^{9}$ However, in sections of lymph-node tissue from another patient with the same diagnosis, $\mathrm{SiO}_{2}$ inclusions were found. Obviously this tissue contained assembled in- haled particles removed from the lung by macrophages. This will be reported in detail in a following paper. ${ }^{10}$

\section{CONCLUSIONS}

It was shown that by using Raman microspectrometry the character of inhaled particles (diameter 1-4 $\mu \mathrm{m}$ ) embedded in lung tissue can be revealed. Some problems arise if the sections are stained, because of the fluorescent background. In unstained sections the localization of inclusions may give rise to difficulties. Further investigations are in progress.

\section{ACKNOWLEDGMENTS}

This study was supported in part by the S.T.W. (Stichting voor Technische Wetenschappen) and the Pieter Langenhuizen Lambertuszoonfonds. The sections were kindly supplied by Dr. J. van der Stadt. Thanks are due to Dr. J. Lankester for helpful discussions.

1. K. F. J. Heinrich, in Proc. Scanning Electron Microscopy Symp., O. Johari, Ed. (Chicago, Illinois, 1977), p. 605.

2. M. Delhaye and P. Dhamelincourt, J. Raman Spect. 3, 33 (1975).

3. G. J. Rosasco and E. S. Etz, Res./Dev. 28, 20 (1977)

4. E. S. Etz, G. J. Rosasco, and W. C. Cunningham, in Environmental Analysis, G. W. Ewing, Ed. (Academic Press, New York, 1977), p. 295.

5. J. L. Abraham and E. S. Etz, Science 206, 716 (1979).

6. W. P. Griffith, in Infrared and Raman Spectroscopy of Lunar and Terrestral Minerals, C. Karr, Jr., Ed. (Academic Press, New York, 1975), Chap. 12, p. 299.

7. H. N. Rutt and J. H. Nicola, J. Phys. C 7, 4522 (1974).

8. D. Krishnamurti, Proc. Indian Acad. Sci. Sect. A 53, 210 (1956).

9. J. Lankester, personal communication.

10. F. F. M. de Mul, H. Buiteveld, J. Lankester, J. Mud, and J. Greve, "Application of Raman Microscopy in Human Pathology," submitted to Journal of Human Pathology.

\title{
Raman Spectroscopic Determination of the Integrity of Urea Inclusion Compounds*
}

\author{
HECTOR L. CASAL \\ Division of Chemistry, National Research Council of Canada, Ottawa, K1A OR6 Canada
}

\begin{abstract}
Raman spectroscopy is shown to provide a rapid and definitive analysis of the nature of urea inclusion compounds. It is demonstrated that the photodecomposition of included alkanones does not destroy the urea lattice, but the inclusion compounds of n-decane are destroyed by ultrasonic agitation.
\end{abstract}

Index Headings: Raman spectra; Urea inclusion compounds.

Urea forms inclusion compounds with paraffin-like molecules ${ }^{1}$ ( $n$-alkanes, fatty acids, etc.). This property has been used successfully to separate linear and branched compounds. ${ }^{1,2}$ While pure urea forms tetragonal crystals, in the inclusion compounds it crystallizes in an hexagonal lattice forming channels of $\sim 0.5 \mathrm{~nm}$

Received 27 June 1983.

* Issued as NRCC Publication No. 23084. diameter. ${ }^{3}$ These channels accommodate linear chain molecules permitting free chain rotation to occur.

Recently, urea inclusion compounds have been shown to provide a unique environment for photochemical reactions. The photodecomposition of included $n$-alkanones was found to occur with greatly differing consequences than is the case for $n$-alkanones in solution. ${ }^{4}$

During the course of these photochemical studies and other investigations on the motions of included molecules, ${ }^{5}$ it became necessary to determine unequivocally if inclusion of the molecules of interest had indeed occurred and if the crystalline lattice had been destroyed during the photochemical reaction.

The crystal structures of free urea (tetragonal) and of the inclusion compounds (hexagonal) present hydrogen bonds of different lengths. ${ }^{3}$ As a result, the vibrations (external and internal) of the urea molecules are differ- 